(2) Open Access Full Text Article

REVIEW

\title{
Irreversible electroporation: state of the art
}

This article was published in the following Dove Press journal:

OncoTargets and Therapy

22 April 2016

Number of times this article has been viewed

\author{
Peter GK Wagstaff' \\ Mara Buijs' \\ Willemien van den Bos' \\ Daniel $M$ de Bruin ${ }^{2}$ \\ Patricia J Zondervan' \\ Jean JMCH de la Rosette' \\ M Pilar Laguna Pes'
}

'Department of Urology, ${ }^{2}$ Department of Biomedical Engineering and Physics, Academic Medical Center, Amsterdam, the Netherlands
Correspondence: PGK Wagstaff Department of Urology, Academic Medical Center University Hospital, Meibergdreef 9, II 05 AZ Amsterdam-

Zuidoost, the Netherlands

$\mathrm{Tel}+3$ I 205666493

Fax +3। 205669585

Email p.g.wagstaff@amc.nl
Abstract: The field of focal ablative therapy for the treatment of cancer is characterized by abundance of thermal ablative techniques that provide a minimally invasive treatment option in selected tumors. However, the unselective destruction inflicted by thermal ablation modalities can result in damage to vital structures in the vicinity of the tumor. Furthermore, the efficacy of thermal ablation intensity can be impaired due to thermal sink caused by large blood vessels in the proximity of the tumor. Irreversible electroporation (IRE) is a novel ablation modality based on the principle of electroporation or electropermeabilization, in which electric pulses are used to create nanoscale defects in the cell membrane. In theory, IRE has the potential of overcoming the aforementioned limitations of thermal ablation techniques. This review provides a description of the principle of IRE, combined with an overview of in vivo research performed to date in the liver, pancreas, kidney, and prostate.

Keywords: irreversible electroporation, IRE, tumor, ablation, focal therapy, cancer

\section{Introduction}

The past decades have yielded significant developments in the field of focal ablative therapy for the treatment of primary tumors or organ-confined distant metastases. Among the practiced techniques are cryoablation, radiofrequency ablation (RFA), microwave ablation, and high-intensity focused ultrasonography. These thermal ablative techniques provide a minimally invasive treatment option in selected tumors in multiple organs such as the liver, lung, pancreas, kidney, and prostate..$^{1-6}$

Focal tumor ablation requires precisely dosed and accurate targeting of the tissue to be ablated while preserving surrounding healthy tissues and vital structures such as blood vessels, nerves, and neighboring organs. ${ }^{7,8}$ The unselective destruction inflicted by thermal ablation modalities can result in damage to vital structures in the vicinity of the tumor. Furthermore, the efficacy of thermal ablation intensity can be impaired due to "thermal sink". Close proximity of large vessels, bile ducts, or the renal collecting system can cause thermal fluctuations, leading to inconsistent ablation results. ${ }^{4,8}$

Irreversible electroporation (IRE) is a novel ablation modality with the potential of overcoming the aforestated limitations of thermal ablation techniques. This review provides a description of the principle of IRE, combined with an overview of in vivo research performed to date in tumors of the liver, pancreas, kidney, and prostate (Table 1). It has to be noted that the development of IRE is simultaneous to that of related techniques based on the same principle, such as electrochemotherapy (ECT), which combines electroporation with chemotherapy. ${ }^{9,10}$ This review is confined to IRE as an ablation technique and does not go into detail on ECT.

\section{Evidence acquisition}

For this nonsystematic review, we performed a literature search of PubMed for original and review articles written in English using the search terms "Irreversible 
Table I Overview of clinical trials focusing on IRE in liver, pancreatic, kidney, and prostate tumors

\begin{tabular}{|c|c|c|c|c|c|c|c|}
\hline Author, year & Organ & $\begin{array}{l}\text { Number of } \\
\text { IRE ablations }\end{array}$ & FU method & FU term & Findings & $\begin{array}{l}\text { Type of } \\
\text { study }\end{array}$ & $\begin{array}{l}\text { Level of } \\
\text { evidence }\end{array}$ \\
\hline $\begin{array}{l}\text { Thomson } \\
\text { et al, }{ }^{36} 2011\end{array}$ & $\begin{array}{l}\text { Liver } \\
\text { Kidney }\end{array}$ & $\begin{array}{l}63 \\
11\end{array}$ & CT & $\begin{array}{l}\text { Directly, I mo } \\
\text { and } 3 \mathrm{mo}\end{array}$ & $\begin{array}{l}\text { In humans, IRE of liver and } \\
\text { kidney tumors is safe if pulses are } \\
\text { synchronized with ECG }\end{array}$ & $\begin{array}{l}\text { Prospective } \\
\text { cohort }\end{array}$ & 4 \\
\hline $\begin{array}{l}\text { Kingham } \\
\text { et al, },^{38} 2012\end{array}$ & Liver & 65 & $\mathrm{CT} / \mathrm{MRI}$ & $\begin{array}{l}\text { Directly, } \\
\text { I/3/6 mo }\end{array}$ & $\begin{array}{l}\text { IRE is safe for the treatment of } \\
\text { liver tumors; one persistence and } \\
\text { one recurrence observed }\end{array}$ & $\begin{array}{l}\text { Retrospective } \\
\text { cohort }\end{array}$ & 4 \\
\hline $\begin{array}{l}\text { Cannon } \\
\text { et } \mathrm{al}^{40} 2013\end{array}$ & Liver & 48 & $\begin{array}{l}\text { CT/MRI/PET, } \\
\text { tumor markers }\end{array}$ & $\begin{array}{l}\text { Directly, } \\
\text { 3-monthly }\end{array}$ & $\begin{array}{l}\text { Initial ablation success in } 100 \% \\
\text { of cases, local recurrence-free } \\
\text { survival } 60 \% \text { at I year; nine low- } \\
\text { grade AEs, all resolved }\end{array}$ & $\begin{array}{l}\text { Prospective } \\
\text { cohort }\end{array}$ & 4 \\
\hline Silk et al, ${ }^{61} 2014$ & Liver & 15 & CT & $\begin{array}{l}\text { Directly, } \\
\text { I-2 mo }\end{array}$ & $\begin{array}{l}\text { Local tumor recurrence in six } \\
\text { of eleven patients (55\%); one } \\
\text { biliary stent placed, possibly due } \\
\text { to contact of IRE electrode with } \\
\text { bile duct }\end{array}$ & $\begin{array}{l}\text { Retrospective } \\
\text { cohort }\end{array}$ & 4 \\
\hline $\begin{array}{l}\text { Cheung et al, }{ }^{41} \\
2013\end{array}$ & Liver & 18 & CT & $\begin{array}{l}\text { I mo, } \\
\text { 3-monthly }\end{array}$ & $\begin{array}{l}\text { Complete ablation in I } 3 \text { ( } 72 \%) \\
\text { lesions; no recurrences at } \\
\text { mean FU of } 18 \text { mo; no serious } \\
\text { complications }\end{array}$ & $\begin{array}{l}\text { Prospective } \\
\text { cohort }\end{array}$ & 4 \\
\hline $\begin{array}{l}\text { Scheffer et al, } \\
2014\end{array}$ & Liver & 10 & Resection & $\begin{array}{l}\text { Ablation- } \\
\text { resection }\end{array}$ & $\begin{array}{l}\text { Macroscopic vitality staining, } \\
\text { nonviable IRE lesion covering } \\
\text { complete tumor in eight of } \\
\text { ten patients; microscopically, } \\
\text { irreversible cell damage in } \\
\text { the tumor-free margin of all } \\
\text { specimens }\end{array}$ & $\begin{array}{l}\text { Prospective } \\
\text { cohort }\end{array}$ & 4 \\
\hline $\begin{array}{l}\text { Cheng et al, }{ }^{42} \\
2015\end{array}$ & Liver & 6 & $\mathrm{CT}$, resection & $\begin{array}{l}\text { I mo, } \\
\text { 3-monthly until } \\
\text { liver transplant }\end{array}$ & $\begin{array}{l}\text { Imaging: complete response in all } \\
\text { cases; pathology: five lesions with } \\
\text { complete necrosis, one lesion } \\
\text { with viable tumor cells }<5 \%\end{array}$ & $\begin{array}{l}\text { Retrospective } \\
\text { cohort }\end{array}$ & 4 \\
\hline $\begin{array}{l}\text { Niessen et al, }{ }^{39} \\
2015\end{array}$ & Liver & 79 & $\mathrm{CT} / \mathrm{MRI}$ & $\begin{array}{l}\text { Directly, } \\
\text { I.5/3/6 mo }\end{array}$ & $\begin{array}{l}\text { Incomplete ablation in two cases; } \\
\text { FU of } 6 \text { mo in } 48 \text { patients, I } 4 \text { ( } 29 \%) \\
\text { of whom showed local recurrence; } \\
\text { risk factors for local recurrence: } \\
\text { tumor volume and tumor type }\end{array}$ & $\begin{array}{l}\text { Prospective } \\
\text { cohort }\end{array}$ & 4 \\
\hline $\begin{array}{l}\text { Sugimoto } \\
\text { et } a l,{ }^{37} 2015\end{array}$ & Liver & 6 & CEUS/CT/MRI & $\begin{array}{l}\text { Directly, } \\
\text { I wk, I mo, } \\
\text { 3-monthly }\end{array}$ & $\begin{array}{l}\text { Complete IRE ablation in five } \\
(83 \%) \text { tumors; residual tumor in } \\
\text { one case at I week; no serious } \\
\text { complications }\end{array}$ & $\begin{array}{l}\text { Prospective } \\
\text { cohort }\end{array}$ & 4 \\
\hline $\begin{array}{l}\text { Narayanan } \\
\text { et al, }{ }^{45} 2012\end{array}$ & Pancreas & 15 & CT & $\begin{array}{l}\text { Directly, I day, } \\
\text { monthly }\end{array}$ & $\begin{array}{l}\text { CT directly and } 24 \text { hours post- } \\
\text { IRE showed patent vasculature in } \\
\text { all cases; no severe complications } \\
\text { or mortality occurred; grade } 2 \\
\text { pancreatitis in one case, resolving } \\
\text { spontaneously }\end{array}$ & $\begin{array}{l}\text { Retrospective } \\
\text { cohort }\end{array}$ & 4 \\
\hline $\begin{array}{l}\text { Paiella et al, }{ }^{46} \\
2015\end{array}$ & Pancreas & 10 & CT & $\begin{array}{l}\text { Directly, } \\
\text { I/2/3 mo }\end{array}$ & $\begin{array}{l}\text { All cases treated successfully; } \\
\text { overall survival: } 7.5 \text { mo; } \\
\text { complications: pancreatic abscess } \\
(n=I) \text { and pancreaticoduodenal } \\
\text { fistula }(n=I)\end{array}$ & $\begin{array}{l}\text { Prospective } \\
\text { cohort }\end{array}$ & 4 \\
\hline $\begin{array}{l}\text { Martin et al, }{ }^{47} \\
2012\end{array}$ & Pancreas & 27 & CT/MRI/PET & $\begin{array}{l}\text { Discharge, } \\
\text { 3-monthly }\end{array}$ & $\begin{array}{l}\text { At } 90 \text { days, no signs of local } \\
\text { recurrence in all patients; } \\
17 \text { possible IRE-related } \\
\text { complications; grade } 4 / 5 \\
\text { complications: bile leak }(n=2) \text { and } \\
\text { portal vein thrombosis }(n=2) \text {; one } \\
\text { mortality at } 70 \text { days }\end{array}$ & $\begin{array}{l}\text { Prospective } \\
\text { cohort }\end{array}$ & 4 \\
\hline
\end{tabular}


Table I (Continued)

\begin{tabular}{|c|c|c|c|c|c|c|c|}
\hline Author, year & Organ & $\begin{array}{l}\text { Number of } \\
\text { IRE ablations }\end{array}$ & FU method & FU term & Findings & $\begin{array}{l}\text { Type of } \\
\text { study }\end{array}$ & $\begin{array}{l}\text { Level of } \\
\text { evidence }\end{array}$ \\
\hline $\begin{array}{l}\text { Martin et al, } \\
2013\end{array}$ & Pancreas & 54 & CT/MRI/PET & $\begin{array}{l}\text { Discharge, } \\
\text { 3-monthly }\end{array}$ & $\begin{array}{l}\text { Improvement IRE vs standard } \\
\text { therapy: local PFS I } 4 \text { vs } 6 \text { mo, } \\
\text { distant PFS I } 5 \text { vs } 9 \text { mo; and overall } \\
\text { survival of } 20 \text { vs I } 3 \text { mo; a total } \\
\text { of } 57 \text { AEs: bile leakage }(n=2) \\
\text { and duodenal leakage }(n=2) \text {; one } \\
\text { mortality occurred }\end{array}$ & $\begin{array}{l}\text { Prospective } \\
\text { cohort }\end{array}$ & 4 \\
\hline $\begin{array}{l}\text { Martin et al, } \\
2015\end{array}$ & Pancreas & 200 & CT/MRI/PET & $\begin{array}{l}\text { Discharge, } \\
\text { 3-monthly }\end{array}$ & $\begin{array}{l}\text { Median overall survival } 24.9 \text { mo } \\
\text { (range: } 4.9-85 \text { mo); complication } \\
\text { rate of } 37 \% \text { (median: grade } 2 \text {, } \\
\text { range: grades I-5); local } \\
\text { recurrence in six (3\%) patients }\end{array}$ & $\begin{array}{l}\text { Prospective } \\
\text { cohort }\end{array}$ & 4 \\
\hline $\begin{array}{l}\text { Pech et al, }{ }^{18} \\
2011\end{array}$ & Kidney & 6 & Resection & $\begin{array}{l}\text { Ablation- } \\
\text { resection }\end{array}$ & $\begin{array}{l}\text { No changes in laboratory blood } \\
\text { results or cardiac function; } \\
\text { pathology (H\&E), swelling of } \\
\text { the ablated cells but no actual } \\
\text { dead cells; no viability staining } \\
\text { performed }\end{array}$ & $\begin{array}{l}\text { Prospective } \\
\text { cohort }\end{array}$ & 4 \\
\hline $\begin{array}{l}\text { Trimmer et al, }{ }^{52} \\
2015\end{array}$ & Kidney & 20 & CT/MRI & $\begin{array}{l}6 \mathrm{wk}, 6 \mathrm{mo}, \\
10 \mathrm{mo}\end{array}$ & $\begin{array}{l}\text { Residual tumor at } 6 \text { wk in two } \\
\text { of } 20 \text { cases; } 6 \text { mo FU available in } \\
\text { I } 5 \text { cases, no signs of recurrence; } \\
\text { I y FU available in six cases, } \\
\text { recurrence in one case; no major } \\
\text { complications observed }\end{array}$ & $\begin{array}{l}\text { Retrospective } \\
\text { cohort }\end{array}$ & 4 \\
\hline $\begin{array}{l}\text { Wendler et al, }{ }^{53} \\
2015\end{array}$ & Kidney & 3 & Resection & 4 wk & $\begin{array}{l}\text { IRE lesions covering all tumors } \\
\text { completely, no residual tumor } \\
\text { in margins; very small tumor } \\
\text { residues of unclear malignancy } \\
\text { observed within the ablation zone, } \\
\text { requiring additional investigation } \\
\text { using viability staining }\end{array}$ & $\begin{array}{l}\text { Prospective } \\
\text { cohort }\end{array}$ & 4 \\
\hline $\begin{array}{l}\text { Onik and } \\
\text { Rubinsky, }{ }^{58} \\
2010\end{array}$ & Prostate & 16 & Biopsy & 3 wk & $\begin{array}{l}\text { All patients remained continent } \\
\text { and potent patients remained so } \\
\text { after IRE; no evidence of cancer } \\
\text { in ablated area in I5 cases; one } \\
\text { patient refused biopsies }\end{array}$ & $\begin{array}{l}\text { Prospective } \\
\text { cohort }\end{array}$ & 4 \\
\hline $\begin{array}{l}\text { Valerio et al, }{ }^{59} \\
2014\end{array}$ & Prostate & 34 & MRI & I wk and 6 mo & $\begin{array}{l}\text { Suspicion of residual disease in six } \\
\text { patients, confirmed with biopsies } \\
\text { in one case; complications: } \\
\text { urinary retention }(n=2) \text {, debris/ } \\
\text { hematuria }(n=6) \text {, dysuria }(n=5) \text {, } \\
\text { urinary tract infection }(n=5)\end{array}$ & $\begin{array}{l}\text { Retrospective } \\
\text { cohort }\end{array}$ & 4 \\
\hline $\begin{array}{l}\text { Van den Bos } \\
\text { et al, }{ }^{29} 2015\end{array}$ & Prostate & 16 & Resection & 4 wk & $\begin{array}{l}\text { Complete ablation of tissue } \\
\text { within the IRE electrode } \\
\text { configuration, no skip lesions; IRE } \\
\text { ablation zone } 2.5-2.9 \text { times larger } \\
\text { than IRE needle configuration }\end{array}$ & $\begin{array}{l}\text { Prospective } \\
\text { cohort }\end{array}$ & 4 \\
\hline
\end{tabular}

Notes: Levels of evidence assigned according to Oxford Centre for Evidence-based Medicine - Levels of Evidence (March 2009); Howick et al (http://www.cebm. net $/$ ? $=1025) . " 1$

Abbreviations: AE, adverse event; CT, computed tomography; ECG, electrocardiogram; FU, follow-up; H\&E, hematoxylin and eosin; IRE, irreversible electroporation; MRI, magnetic resonance imaging; mo, months; PET, positron emission tomography; PFS, progression-free survival; wk, weeks; $y$, years; CEUS, contrast enhanced ultrasound.

Electroporation", combined with "liver", "pancreas", "kidney", and "prostate". This search resulted in 203 hits, from which we selected 20 articles based on relevant contribution to clinical evaluation of IRE (Table 1). Case reports were excluded. The selected articles had been published from 2011 to 2015, and $40 \%$ of the papers were published in 2015. Levels of evidence were assigned to the selected articles according to the Oxford Centre for Evidence-based 
Medicine's "Levels of Evidence". ${ }^{11}$ The reference lists of the selected papers were scrutinized for additional relevant articles (yielding 41 articles).

\section{IRE principle}

IRE is based on the principle of electroporation or electropermeabilization, in which electric pulses are used to create nanoscale defects in the cell membrane. These defects, termed "nanopores" or "conductive pores", permeate the cell membrane, permitting molecules to pass into the targeted cells. ${ }^{8,12,13}$ Nanopore formation can be temporary (reversible electroporation), as used in the fields of gene transfection or ECT. 9,14,15 Above a certain electrical threshold, the "nanopores" become permanent, causing cell death due to the inability to maintain homeostasis (IRE), as used in the food industry for sterilization and, more recently, in medicine for tumor ablation. ${ }^{16-18}$ The occurrence of IRE was initially considered an unwanted treatment side effect during reversible electroporation procedures. In the past decade, however, the focus has turned to IRE as an ablation modality, resulting in the development of a commercially available IRE console designed specifically for tissue ablation. ${ }^{8,19}$

The presence of nanopores following the delivery of electrical pulses has been visualized using electron microscopy, showing temporary and permanent nanopores. ${ }^{12,13}$ The pulse-induced disturbances of the cells as a whole were studied using fluorescence microscopy. ${ }^{20,21}$ Because direct visualization of cell poration is difficult to follow over time, researchers have used indirect measures to quantify the effect of electroporation, such as changes in electrical conductivity or the uptake of dye following the admission of electrical pulses. $^{22,23}$ However, visualization of membrane pores following the application of pulses does not definitively prove them to be the cause of IRE-induced cell death. Furthermore, ex vivo and animal research results have shown that IRE using the current clinically practiced treatment settings causes substantial increase in temperature in the targeted tissue. ${ }^{24-26}$ This secondary temperature development raises the question regarding the extent of the IRE effect that is caused by the temperature change versus that due to cell membrane poration. Therefore, as the field of tumor ablation using IRE progresses at a rapid pace, its underlying mechanism remains a subject of debate. ${ }^{16,24,27}$

If we assume instead of temperature development, the theory of cell membrane poration, IRE is not dependent on thermal energy and is therefore not influenced by "thermal sink", promising consistent results in the vicinity of large vessels or the renal collecting system. Furthermore, IRE should be defined so as to limit damage of the cell membrane, spare tissue architecture, and minimize damage to blood vessels, nerves, and the renal collecting system. ${ }^{28}$ IRE lesions show a sharp demarcation between ablated and nonablated tissues, whereas thermal ablation techniques show a transitional zone of partially damaged tissue wherein insufficient temperatures were reached for definitive ablation. ${ }^{29}$ This indicates that IRE ablation boundaries can potentially be planned more precisely compared to conventional techniques.

\section{IRE device and procedure}

The first, and at the time of writing only, commercially available IRE console for clinical use in tissue ablation is the NanoKnife ${ }^{\mathrm{TM}}$, also registered as the HVP-01 Electroporation System (Angiodynamics Inc, Queensbury, NY, USA). The system carries a CE mark and has US Food and Drug Administration approval for soft tissue ablation. The NanoKnife ${ }^{\mathrm{TM}}$ platform consists of a low-energy direct current generator interfaced with a computer system equipped with user-friendly treatment planning software (Figure 1A and B). The system has the capability of connecting up to six monopolar needle electrodes, $16 \mathrm{G}$ in diameter and covered in a retractable insulation sheath, allowing for the adjustment of the active tip length (Figure 1C). Bipolar IRE electrodes are available; however, these are not commonly used after early animal research showed bipolar IRE to result in lower ablation volumes, combined with a higher risk of collateral damage. ${ }^{30}$

Further parameters to be adjusted in IRE ablation are voltage, pulse number, pulse length, electrode number, and electrode spacing. The parameters can be entered into the IRE console, which subsequently generates a two-dimensional (2D) representation of the ablation shape, perpendicular to the direction of the inserted needle electrodes (Figure 1B). Knowledge on how to tailor IRE settings to specific tissue/tumor types remains limited. Research into simulation of the IRE ablation zone, in order to aid IRE ablation planning, is under way but has not yet yielded accurate results. ${ }^{31}$ Except for slight variations, IRE settings are similar for most research into tumor ablation. Currently practiced IRE settings for tumor ablation are voltage $1,500 \mathrm{~V} / \mathrm{cm}$, $70-90$ pulses of 70-90 $\mu \mathrm{s}$, electrode spacing $1.5-2 \mathrm{~cm}$, and active electrode tip length $1-1.5 \mathrm{~cm}$.

In order to prevent complications as a result of the administration of high-intensity electrical pulses, two main precautions are generally taken during IRE procedures. First, to prevent severe muscle contractions, IRE procedures take place under general anesthesia with additional 
A

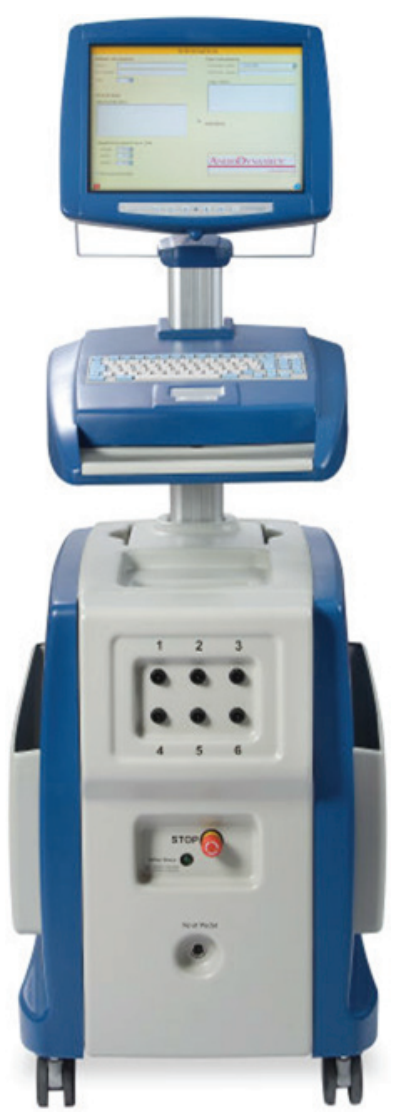

B

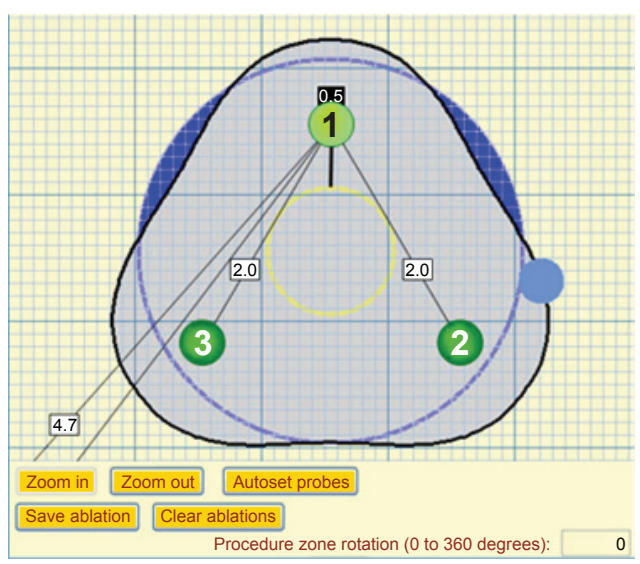

D

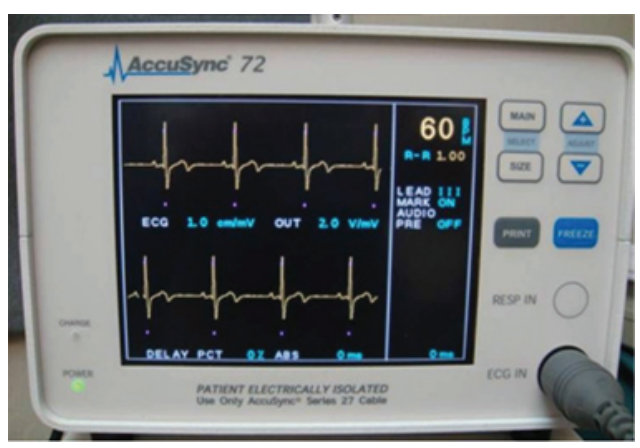

C

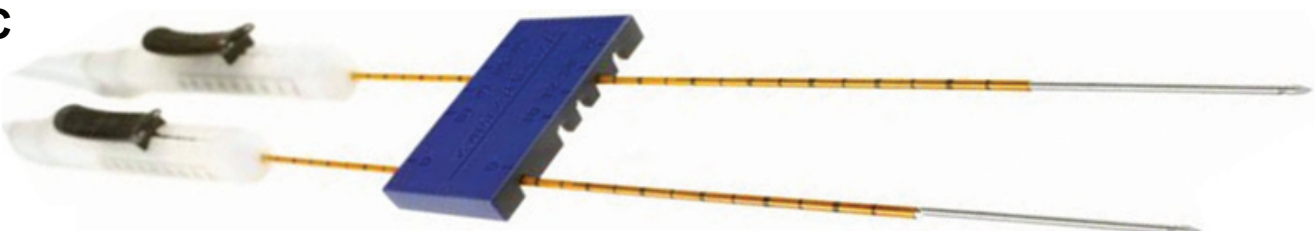

Figure I IRE equipment.

Notes: (A) The NanoKnife ${ }^{\mathrm{TM}}$ IRE console. (B) User-friendly treatment planning software generates a 2D representation of the ablation zone, perpendicular to the direction of the inserted needle electrodes. (C) Monopolar needle electrodes (I6 G), covered in a retractable insulation sheath, allowing for adjustment of the active tip length. The blue spacer allows for parallel external fixation of the IRE needles. (D) AccuSync ECG synchronizer, allowing for synchronization of the IRE pulses with the cardiac rhythm. Abbreviations: ECG, electrocardiogram; IRE, irreversible electroporation; 2D, two-dimensional.

muscle relaxation. ${ }^{32}$ Second, the administered IRE pulses could potentially cause cardiac arrhythmia, depending on the distance of the ablation spot to the heart. ${ }^{36}$ Therefore, synchronization of the IRE pulses with the cardiac rhythm is advised. A synchronization device can be interfaced to the IRE console to ensure accurate pulse timing (Figure 1D). The IRE electrodes are positioned under computed tomography (CT) and/or ultrasound guidance in a similar manner to RFA or cryoablation probes. In order to guarantee an equal distribution of the electrical field, the electrodes need to be placed exactly parallel. External spacers are available to interlock the electrodes (Figure 1C). In prostate ablations, a brachytherapy grid can be used for needle targeting and fixation. ${ }^{29}$

\section{In vivo IRE results Liver}

Conventional thermal ablation techniques, specifically RFA, have been proven effective in the treatment of hepatic tumors in selected patients. ${ }^{33,34}$ Thermal ablation in the liver is limited by the risk of thermal damage to large vessels, bile ducts, gall bladder, hepatic capsule, and extrahepatic organs. ${ }^{35}$ Furthermore, the presence of large vessels may lead to heat sink, impairing ablation results.

IRE of tumors of the liver is the most extensively investigated, with nine trials reporting on its efficacy and safety (Table 1). In terms of safety, all nine studies concluded that IRE was well tolerated by patients, and that IRE is safe for treating liver tumors under the condition that the procedure 
is electrocardiographically synchronized to the cardiac rhythm. ${ }^{36,37}$ IRE was especially feasible in tumors with close proximity to major vital structures, for instance, bile ducts, portal veins, and arteries..$^{38,39}$

The tumor response rate varied from $50 \%$ to $98.1 \% .^{36-38,40-42}$ Highest response rates were described in patients with a median tumor size of $1 \mathrm{~cm}$ in high-risk locations, such as perivascular regions and positions close to major biliary structures, investigated by Kingham et al. ${ }^{38}$ Lowest response rates were demonstrated in patients with liver metastasis from numerous different primary tumors, fluctuating from 1.7 to $6.3 \mathrm{~cm}$ in size. ${ }^{36}$ The overall local recurrences at 6-month follow-up varied from $0 \%$ to $55 \% .^{38-41}$

The aforementioned response rates and recurrences vary widely across studies, which is probably due to the heterogeneity of patient populations, ablation protocols, and tumor characteristics.

In conclusion, success of IRE in the liver mainly depends on lesion size. Thomson et $\mathrm{al}^{36}$ reported that liver metastases $>5 \mathrm{~cm}$ did not show any response with regard to tumor control. When four or more unipolar electrodes are required to ablate one lesion, the overall response rate decreases drastically. This is imaginable because it is technically challenging to place a multiple-needle array. Additionally, the field of electrical impulses is wider and therefore less controllable. A further risk factor associated with local recurrence after IRE is tumor type, with hepatocellular carcinoma (HCC) being less associated with recurrence than metastatic disease $(P=0.023$ for HCC, cholangiocellular carcinoma, or metastatic disease). ${ }^{39}$

Early results of IRE appear to be promising for small liver lesions close to vital structures, as no complications that were directly related to the IRE ablation were described. Nonetheless, comparative studies with conventional thermal ablative therapies need to be carried out to prove its oncological efficacy.

\section{Pancreas}

Pancreatic tumors are aggressive in nature. Furthermore, they are generally complicated to treat due to close proximity to vital structures, such as the portal vein, the celiac trunk, and the superior mesenteric vein. ${ }^{43}$ In patients with unresectable locally advanced pancreatic cancer (LAPC), RFA has been shown to improve survival. However, RFA treatment is characterized by a high rate of complications. ${ }^{44}$

Narayanan et $\mathrm{a}^{45}$ evaluated the safety of percutaneous pancreatic IRE in 15 ablations in 14 patients. No severe complications or mortality occurred. One patient developed a grade 2 pancreatitis, which resolved spontaneously.
Similarly, Paiella et a ${ }^{46}$ reported on the safety and feasibility of pancreatic IRE in ten patients diagnosed with unresectable LAPC. Two complications were observed, namely, a pancreatic abscess and a pancreaticoduodenal fistula, both in the same patient.

A considerable amount of experience in pancreatic IRE has been obtained by the research of Martin et al. ${ }^{47-49}$ Starting with a pilot study in 27 patients, aimed at studying the safety and feasibility of pancreatic IRE, ${ }^{47} 17$ possible IRErelated complications were reported in four patients, ranging from grades 1 to 5 . Grade 4 and grade 5 complications consisted of bile leak $(n=2)$ and portal vein thrombosis $(n=2)$. One mortality occurred at 70 days post-IRE. This was due to portal vein thrombosis, which was presumably induced or worsened by the IRE treatment. At 90-day follow-up, none of the patients showed signs of local recurrence. ${ }^{47}$ In a subsequent study, Martin et al reported on pancreatic IRE in a group of 54 unresectable LAPCs. ${ }^{48}$ When comparing IRE patients to those on standard therapy, an improvement in local progression-free survival was observed (14 vs 6 months; $P=0.01$ ), distant progression-free survival ( 15 vs 9 months; $P=0.02$ ), and overall survival (20 vs 13 months; $P=0.03$ ). A total of 67 adverse events were reported in 32 patients of the IRE group, including two cases of bile leakage and two cases of duodenal leakage. One mortality occurred post-pancreatic IRE. ${ }^{48}$ A recent analysis of 200 LAPC stage III patients treated with IRE in addition to conventional chemotherapy and radiation therapy showed equally promising results. ${ }^{49}$ Median overall survival in these patients was 24.9 months (range: 4.9-85 months), at a complication rate of $37 \%$ (median: grade 2, range: grades $1-5)$. In six (3\%) patients, a local recurrence was observed. ${ }^{49}$

According to these studies, IRE has proven to be an effective treatment in pancreatic carcinomas, with an improvement in progression-free survival and overall survival when compared to chemotherapy or chemoradiation therapy. However, a few limitations deserve consideration. Sample sizes are small and therefore confine the clinical evidence. We recommend that trials should be repeated with larger populations. Additionally, complication rates are high and severe in nature. A major part of the aforementioned studies included unresectable pancreatic carcinomas, a population that is known for its high morbidity and mortality. Due to high complication rates and the aggressive nature of these tumors, it might be difficult to determine the overall effect of IRE in pancreatic carcinomas. However, first results indicate that IRE is a suitable option and should be considered in patients diagnosed with unresectable pancreatic carcinoma. 


\section{Kidney}

The alternative for nephron-sparing surgery is the use of RFA or cryoablation in selected patients presenting with a small renal mass $(\leq 4 \mathrm{~cm})$. Oncologic outcomes of ablative therapies are slightly lower compared to the results from conventional surgery; this is, however, balanced by a lower complication rate and a preservation of renal function..$^{50,51}$ Thermal ablative treatments are contraindicated for tumors in close proximity to the renal collecting system, the large blood vessels, or the abdominal organs. IRE could potentially extend the application of focal therapy in kidney cancer if proven safe and reliable in these high-risk locations.

The first-in-human study into the feasibility and safety of IRE ablation of renal cell carcinoma was performed by Pech et al. ${ }^{18}$ This "ablate-and-resect" pilot study included six patients with a renal mass requiring radical nephrectomy. IRE was performed under anesthesia immediately before resection of the kidney. In one patient, a single intraoperative supraventricular extrasystole was encountered, without any further electrocardiographic abnormalities during follow-up. Histopathological examination, using hematoxylin and eosin staining, of the resected tumors showed swelling of the ablated cells, but no actual dead cells were observed. ${ }^{18}$ No additional viability staining was performed.

Thomson et $\mathrm{a}^{36}$ investigated the safety of IRE in renal masses in their multiple organ (liver, lung, and kidney) IRE study. IRE of the kidney was performed in ten tumors of seven patients. One patient developed an obstruction of the ureter, which previously had been obstructed as a result of RFA ablation treatment. None of the remaining patients showed signs of stricture while the ureter or collecting system was within the ablation zone. Two patients suffered transient hematuria, both of whom had received IRE treatment extending into the central portion of the kidney. Two patients required a second IRE treatment after 3 months of follow-up. ${ }^{36}$

Trimmer et al ${ }^{52}$ reported on 20 cases of IRE in small renal masses, with 1 year of imaging follow-up. Two out of the 20 cases presented with residual tumor at 6-week follow-up imaging and were treated with salvage RFA. Six-month follow-up was available in 15 cases showing no signs of recurrence. One-year follow-up was available in six cases, showing recurrence in one case, which was treated by partial nephrectomy. No major complications were observed. ${ }^{52}$

The most recent report on renal mass IRE is from Wendler et al, ${ }^{53}$ providing preliminary results of a trial in which the IRE lesions are resected 4 weeks postablation. This interim report describes the results in the first three patients and gives a detailed report on the histopathology of an IRE ablation zone. The IRE lesions cover all three tumors completely, with no residual tumor in the margins. Very small tumor residues of unclear malignancy have been observed within the ablation zone. The viability, and with that the oncological consequence, of these small residues is unclear. The authors aim to perform additional viability staining in more patients to further investigate this issue. ${ }^{53}$

It is concluded that IRE is safe and feasible in the treatment of kidney tumors. No major complications occurred in any of the studies. Nonetheless, the golden standard, a laparoscopic partial nephrectomy, is a highly effective minimally invasive treatment, which is accompanied by very low complication rates and side effects. Therefore, we consider that IRE should be considered in patients diagnosed with renal tumors close to vital structures as only a second-line treatment.

\section{Prostate}

Prostate cancer is the most prevalent form of cancer in men, with an increase in detection of localized disease in the Western world due to the use of prostate-specific antigen testing and improved imaging techniques. ${ }^{29,54}$ Conventional therapies in prostate cancer (prostatectomy and radiotherapy) are associated with high incidence of treatment side effects. Common side effects resulting from the destructive nature of conventional treatment include urinary incontinence ( $0 \%-20 \%)$, bowel problems ( $22 \%-36 \%)$, and erectile dysfunction (19\%-74\%). ${ }^{55-57}$ Focal therapies, including IRE, have the potential to reduce these burdens by sparing vital structures such as the urethra and the neurovascular bundles.

The first to report on the use of IRE in prostate cancer were Onik and Rubinsky, ${ }^{58}$ treating 16 patients with localized cancer for whom preservation of potency and continence was a major concern. All patients were continent immediately upon removal of the catheter 0-3 days posttreatment. Patients who were potent before remained so after IRE treatment. However, two patients who received bilateral IRE treatment required 6 months for full return of potency. Treatment success was determined after 3 weeks by transperineal biopsies. Fifteen patients showed no evidence of cancer in the targeted area, with one patient refusing follow-up. In one patient, a microfocus Gleason 6 cancer was found outside the targeted area. ${ }^{58}$

Valerio et al ${ }^{59}$ performed IRE of prostate cancer in 34 patients, assessing safety and feasibility. A total of 12 grade 1 complications and ten grade 2 complications occurred. Follow-up consisted of multiparametric magnetic 
resonance imaging (MRI) at 1 week and 6 months post-IRE. Complications included urinary retention $(n=2 ; 6 \%)$, debris/ hematuria $(n=6 ; 18 \%)$, dysuria $(n=5 ; 15 \%)$, and urinary tract infection $(n=5 ; 15 \%)$. Six patients $(18 \%)$ showed suspicion of residual disease, four of whom underwent a secondary treatment. Only one patient had histological confirmation of treatment failure, through transperineal biopsies, and decided to undergo a radical prostatectomy. ${ }^{59}$

Recently, Van den Bos et $\mathrm{al}^{29}$ performed an ablate-andresect study, performing IRE in 16 prostate cancer patients 4 weeks prior to radical prostatectomy. Their study focused on safety and feasibility, not specifically targeting the prostate cancer, and therefore did not present results on cancer-free rates. However, pathology results showed complete ablation of tissue (necrosis and fibrosis) within the IRE electrode configuration. Furthermore, the IRE ablation zones were found to extend beyond the IRE needles, with three needle ablations being 2.9 times larger than the needle configuration and four needle ablations being 2.5 times larger. Importantly, no skip lesions were observed within the needle configuration. ${ }^{29}$

In theory, focal treatment in prostate cancer is a promising approach as current conventional therapies have a lot of limitations. Radical prostatectomy and radiotherapy both have poor functional outcomes, with high rates of urinary incontinence and erectile dysfunction. It is believed that IRE has the potential to overcome these side effects. However, to date, there is little evidence on oncological outcome and no long-term results of IRE in prostate cancer are available. To our knowledge, there is sufficient evidence to say that IRE is a safe and effective focal treatment modality in prostate cancer, but a large trial is needed to warrant its oncological efficacy.

\section{Considerations and future perspectives}

The introduction of new treatment techniques should adhere to a standardized methodology, such as the IDEAL recommendations. ${ }^{60}$ Following such guidelines will result in a stepwise, safe, and scientifically valid evaluation of the new technique at hand. Research into in vivo IRE is focusing on several different organs simultaneously, with progress being at a different stage for each field. Although IRE research in liver and pancreas is leading the way, it is important to not take these results as evidence for the safety and efficacy of IRE in other organs, that is, skipping ahead in the organspecific evaluation of IRE.

Several trials are expected to provide additional evidence on in vivo IRE in the near future. The COLDFIRE-II trial
(NCT02082782) is aimed at including 29 patients with colorectal liver metastasis for treatment with percutaneous CT-guided IRE, with follow-up by positron emission tomography (PET)-CT and PET-MRI. The same research group is finalizing the results of the PANFIRE trial (NCT01939665), having included 15 patients with locally advanced pancreatic adenocarcinoma, treated with percutaneous IRE and subsequently followed by cross-sectional imaging (CT/MRI) and blood tumor markers. Two further trials focusing on IRE in pancreatic cancer are the IMPALA trial (NL44713.018.13) and the pancreatic IRE trial (NL45048.058.13) at the Leiden University (the Netherlands).

Although the evidence on IRE in different organs is rapidly expanding, most results remain in the form of lowquality cohort studies, to be graded as level 4 of evidence. ${ }^{11}$ Different groups are collaborating by pooling IRE data in registries. Uniform and central collection of data will result in larger data sets, allowing for more substantial evaluation of IRE safety and efficacy. Examples of such registries are the Soft Tissue Ablation Registry (STAR) and the prostate IRE registry (NCT02255890) of the Clinical Research Office of the Endourological Society (CROES). A considerable improvement on the available evidence will come from the CROES coordinated multicenter randomized controlled trial (RCT) (level 2b) into IRE in prostate cancer (NCT01835977). This recently started RCT will compare the IRE safety and efficacy between a focal IRE ablation and extended IRE ablation of the prostate.

For IRE to evolve into an accepted segment of standard therapy more research is needed, directed at tissue-specific device settings and ablation protocols, further evaluation of early ablation results, and follow-up methods, completed by studies focused on long-term oncological outcomes. At this phase of development, it is essential to perform IRE as much as possible in the setting of a clinical trial. As it involves the use of a medical device instead of a pharmacological product, the optimal way to proceed is following the recommendations of the IDEAL collaboration. ${ }^{60}$ This evaluation equals surgical innovation to the different phases of pharmacological research. IRE has been described for the IDEAL stage 2 a (development phase). To develop IRE into a minimally invasive treatment device, results should be compared with a standard test at use in Phase IIb and Phase III RCT trials. The best trial for the clinical evaluation of a new technique is an RCT. These trials are, however, seldom undertaken because they are time consuming and expensive. The common trial design, a prospective cohort, should consist of a strict treatment protocol in combination with a clearly 
defined population. If inclusion in a trial is not possible, patient data should at least be pooled uniformly in a centrally coordinated registry.

\section{Conclusion}

IRE is showing promising results in early clinical research. The prospect of treating tumors in the vicinity of vital structures gives IRE a potential edge over conventional ablation techniques, which are mainly thermal in nature. However, for IRE to evolve into a clinically accepted ablation technique, further development is needed on multiple fronts, namely, tissue-specific device settings/protocols, ablation monitoring, and follow-up imaging, as well as long-term oncological outcomes. At this stage of development, it is essential to perform IRE in the setting of well-designed clinical trials and, if trial participation is not possible, at least to pool patients in a registry. Furthermore, as electrical properties vary among different tissue types, it is important not to interchange outcomes between organs, undermining the organ-specific evaluation of IRE.

\section{Disclosure}

PGKW, MB, and WB received an unrestricted research grant from the Cure for Cancer Foundation (www.cureforcancer.nl). JJMCHdR is a paid consultant for AngioDynamics. The authors report no other conflicts of interest in this work.

\section{References}

1. Lencioni R, Cioni D, Della Pina C, Crocetti L. Hepatocellular carcinoma: new options for image-guided ablation.JHepatobiliary Pancreat Sci.2010; 17:399-403.

2. Sharma A, Abtin F, Shepard JA. Image-guided ablative therapies for lung cancer. Radiol Clin North Am. 2012;50:975-999.

3. Volpe A, Cadeddu JA, Cestari A, et al. Contemporary management of small renal masses. Eur Urol. 2011;60:501-515.

4. Olweny EO, Cadeddu JA. Novel methods for renal tissue ablation. Curr Opin Urol. 2012;22:379-384.

5. Valerio M, Ahmed HU, Emberton M, et al. The role of focal therapy in the management of localised prostate cancer: a systematic review. Eur Urol. 2014;66:732-751.

6. van den Bos W, Muller BG, Ehdaie B, Scardino P, de la Rosette JJ. What is still needed to make focal therapy an accepted segment of standard therapy? Curr Opin Urol. 2014;24:247-255.

7. Rubinsky B, Onik G, Mikus P. Irreversible electroporation: a new ablation modality - clinical implications. Technol Cancer Res Treat. 2007; $6: 37-48$.

8. Wagstaff PG, de Bruin DM, Zondervan PJ, et al. The efficacy and safety of irreversible electroporation for the ablation of renal masses: a prospective, human, in-vivo study protocol. BMC Cancer. 2015;15:165.

9. Miklavcic D, Mali B, Kos B, Heller R, Sersa G. Electrochemotherapy: from the drawing board into medical practice. Biomed Eng Online. 2014;13:29.

10. Yarmush ML, Golberg A, Sersa G, Kotnik T, Miklavcic D. Electroporation-based technologies for medicine: principles, applications, and challenges. Annu Rev Biomed Eng. 2014;16:295-320.
11. Oxford Centre for Evidence-based Medicine - Levels of Evidence. Howick J, Phillips B, Ball C, et al, Centre for Evidence-Based Medicine, University of Oxford; 2009. Available from: http:/www.cebm.net/ oxford-centre-evidence-based-medicine-levels-evidence-march-2009/. Accessed October 1, 2015.

12. Lee EW, Wong D, Prikhodko SV, et al. Electron microscopic demonstration and evaluation of irreversible electroporation-induced nanopores on hepatocyte membranes. J Vasc Interv Radiol. 2012;23:107-113.

13. Chang DC, Reese TS. Changes in membrane-structure induced by electroporation as revealed by rapid-freezing electron-microscopy. Biophys J. 1990;58:1-12.

14. Neumann E, Schaeferridder M, Wang Y, Hofschneider PH. Genetransfer into mouse lyoma cells by electroporation in high electric-fields. EMBO J. 1982;1:841-845.

15. Mir LM, Orlowski S, Belehradek J, Paoletti C. Electrochemotherapy potentiation of antitumor effect of bleomycin by local electric pulses. Eur J Cancer. 1991;27:68-72.

16. Al-Sakere B, Andre F, Bernat C, et al. Tumor ablation with irreversible electroporation. PLoS One. 2007;2:e1135.

17. Olweny EO, Kapur P, Tan YK, Park SK, Adibi M, Cadeddu JA. Irreversible electroporation: evaluation of nonthermal and thermal ablative capabilities in the porcine kidney. Urology. 2013;81:679-684.

18. Pech M, Janitzky A, Wendler JJ, et al. Irreversible electroporation of renal cell carcinoma: a first-in-man phase I clinical study. Cardiovasc Intervent Radiol. 2011;34:132-138.

19. Bertacchini C, Margotti PM, Bergamini E, Lodi A, Ronchetti M, Cadossi R. Design of an irreversible electroporation system for clinical use. Technol Cancer Res Treat. 2007;6:313-320.

20. Kinosita K, Ashikawa I, Saita N, et al. Electroporation of cell-membrane visualized under a pulsed-laser fluorescence microscope. Biophys J. 1988; 53:1015-1019.

21. Hibino M, Shigemori M, Itoh H, Nagayama K, Kinosita K. Membrane conductance of an electroporated cell analyzed by submicrosecond imaging of transmembrane potential. Biophys J. 1991;59:209-220.

22. Jiang CL, Davalos RV, Bischof JC. A Review of basic to clinical studies of irreversible electroporation therapy. IEEE Trans Biomed Eng. 2015;62:4-20.

23. Granot Y, Ivorra A, Maor E, Rubinsky B. In vivo imaging of irreversible electroporation by means of electrical impedance tomography. Phys Med Biol. 2009;54:4927-4943.

24. van Gemert MJ, Wagstaff PG, de Bruin DM, et al. Irreversible electroporation: just another form of thermal therapy? Prostate. 2015;75(3): $332-335$.

25. Wagstaff PG, de Bruin DM, van den Bos W, et al. Irreversible electroporation of the porcine kidney: temperature development and distribution. Urol Oncol. 2015;33(4):168.e1-168.e7.

26. van den Bos W, Scheffer HJ, Vogel JA, et al. Thermal energy during irreversible electroporation and the influence of different ablation parameters. J Vasc Interv Radiol. Epub 2015 Dec 17.

27. Davalos RV, Bhonsle S, Neal RE. Implications and considerations of thermal effects when applying irreversible electroporation tissue ablation therapy. Prostate. 2015;75:1114-1118.

28. Golberg A, Yarmush ML. Nonthermal irreversible electroporation: fundamentals, applications, and challenges. IEEE Trans Biomed Eng. 2013;60:707-714.

29. van den Bos W, de Bruin DM, Jurhil RR, et al. The correlation between the electrode configuration and histopathology of Irreversible Electroporation ablations in prostate cancer patients. World J Urol. Epub 2015 Aug 22.

30. Tracy CR, Kabbani W, Cadeddu JA. Irreversible electroporation (IRE): a novel method for renal tissue ablation. BJU Int. 2011;107: 1982-1987.

31. Wimmer T, Srimathveeravalli G, Gutta N, et al. Planning irreversible electroporation in the porcine kidney: are numerical simulations reliable for predicting empiric ablation outcomes? Cardiovasc Intervent Radiol. 2015;38:182-190. 
32. Nielsen K, Scheffer HJ, Vieveen JM, et al. Anaesthetic management during open and percutaneous irreversible electroporation. Br J Anaesth. 2014;113:985-992.

33. Bruix J, Sherman M. Management of hepatocellular carcinoma: an update. Hepatology. 2011;53:1020-1022.

34. Cho YK, Kim JK, Kim MY, Rhim H, Han JK. Systematic review of randomized trials for hepatocellular carcinoma treated with percutaneous ablation therapies. Hepatology. 2009;49:453-459.

35. Teratani T, Yoshida H, Shiina S, et al. Radiofrequency ablation for hepatocellular carcinoma in so-called high-risk locations. Hepatology. 2006;43:1101-1108.

36. Thomson KR, Cheung W, Ellis SJ, et al. Investigation of the safety of irreversible electroporation in humans. J Vasc Interv Radiol. 2011;22: 611-621.

37. Sugimoto K, Moriyasu F, Kobayashi Y, et al. Irreversible electroporation for nonthermal tumor ablation in patients with hepatocellular carcinoma: initial clinical experience in Japan. Jpn J Radiol. 2015;33:424-432.

38. Kingham TP, Karkar AM, D'Angelica MI, et al. Ablation of perivascular hepatic malignant tumors with irreversible electroporation. J Am Coll Surg. 2012;215:379-387.

39. Niessen C, Igl J, Pregler B, et al. Factors associated with short-term local recurrence of liver cancer after percutaneous ablation using irreversible electroporation: a prospective single-center study. J Vasc Interv Radiol. 2015;26:694-702.

40. Cannon R, Ellis S, Hayes D, Narayanan G, Martin RC. Safety and early efficacy of irreversible electroporation for hepatic tumors in proximity to vital structures. J Surg Oncol. 2013;107:544-549.

41. Cheung W, Kavnoudias H, Roberts S, Szkandera B, Kemp W, Thomson KR. Irreversible electroporation for unresectable hepatocellular carcinoma: initial experience and review of safety and outcomes. Technol Cancer Res Treat. 2013;12:233-241.

42. Cheng RG, Bhattacharya R, Yeh MM, Padia SA. Irreversible electroporation can effectively ablate hepatocellular carcinoma to complete pathologic necrosis. J Vasc Interv Radiol. 2015;26:1184-1188.

43. Yeo CJ. Pancreatic cancer - in brief. Curr Probl Cancer. 2002;26:170.

44. Pandya GJ, Shelat VG. Radiofrequency ablation of pancreatic ductal adenocarcinoma: the past, the present and the future. World J Gastrointest Oncol. 2015;7:6-11.

45. Narayanan G, Hosein PJ, Arora G, et al. Percutaneous irreversible electroporation for downstaging and control of unresectable pancreatic adenocarcinoma. J Vasc Interv Radiol. 2012;23:1613-1621.

46. Paiella S, Butturini G, Frigerio I, et al. Safety and feasibility of Irreversible Electroporation (IRE) in patients with locally advanced pancreatic cancer: results of a prospective study. Dig Surg. 2015;32:90-97.

47. Martin RC, McFarland K, Ellis S, Velanovich V. Irreversible electroporation therapy in the management of locally advanced pancreatic adenocarcinoma. J Am Coll Surg. 2012;215:361-369.

48. Martin RC, McFarland K, Ellis S, Velanovich V. Irreversible electroporation in locally advanced pancreatic cancer: potential improved overall survival. Ann Surg Oncol. 2013;20(suppl 3):S443-S449.
49. Martin RC, Kwon D, Chalikonda S, et al. Treatment of 200 locally advanced (Stage III) pancreatic adenocarcinoma patients with irreversible electroporation: safety and efficacy. Ann Surg. 2015;262: 486-494.

50. Katsanos K, Mailli L, Krokidis M, McGrath A, Sabharwal T, Adam A. Systematic review and meta-analysis of thermal ablation versus surgical nephrectomy for small renal tumours. Cardiovasc Intervent Radiol. 2014;37:427-437.

51. Wagstaff P, Ingels A, Zondervan P, de la Rosette JJ, Laguna MP. Thermal ablation in renal cell carcinoma management: a comprehensive review. Curr Opin Urol. 2014;24:474-482.

52. Trimmer CK, Khosla A, Morgan M, Stephenson SL, Ozayar A, Cadeddu JA. Minimally invasive percutaneous treatment of small renal tumors with irreversible electroporation: a single-center experience. J Vasc Interv Radiol. 2015;26(10):1465-1471.

53. Wendler JJ, Ricke J, Pech M, et al. First delayed resection findings after irreversible electroporation (IRE) of human localised renal cell carcinoma (RCC) in the IRENE pilot Phase 2a trial. Cardiovasc Intervent Radiol. 2015;39(2):239-250.

54. Jemal A, Siegel R, Xu J, Ward E. Cancer statistics, 2010. CA Cancer J Clin. 2010;60:277-300.

55. Resnick MJ, Koyama T, Fan KH, et al. Long-term functional outcomes after treatment for localized prostate cancer. $N$ Engl J Med. 2013;368:436-445.

56. Ficarra V, Novara G, Ahlering TE, et al. Systematic review and metaanalysis of studies reporting potency rates after robot-assisted radical prostatectomy. Eur Urol. 2012;62:418-430.

57. Ficarra V, Novara G, Rosen RC, et al. Systematic review and metaanalysis of studies reporting urinary continence recovery after robotassisted radical prostatectomy. Eur Urol. 2012;62:405-417.

58. Onik G, Rubinsky B. Irreversible electroporation: first patient experience focal therapy of prostate cancer. In: Rubinsky B, editor. Irreversible Electroporation. Berlin Heidelberg: Springer-Verlag; 2010:235-247.

59. Valerio M, Stricker PD, Ahmed HU, et al. Initial assessment of safety and clinical feasibility of irreversible electroporation in the focal treatment of prostate cancer. Prostate Cancer Prostatic Dis. 2014; 17:343-347.

60. McCulloch P, Altman DG, Campbell WB, et al. No surgical innovation without evaluation: the IDEAL recommendations. Lancet. 2009; 374:1105-1112.

61. Silk MT, Wimmer T, Lee KS, et al. Percutaneous ablation of peribiliary tumors with irreversible electroporation. J Vasc Interv Radiol. 2014;25:112-118

62. Scheffer HJ, Nielsen K, van Tilborg AA, et al. Ablation of colorectal liver metastases by irreversible electroporation: results of the COLDFIRE-I ablate-and-resect study. Eur Radiol. 2014;24:2467-2475.
OncoTargets and Therapy

\section{Publish your work in this journal}

OncoTargets and Therapy is an international, peer-reviewed, open access journal focusing on the pathological basis of all cancers, potential targets for therapy and treatment protocols employed to improve the management of cancer patients. The journal also focuses on the impact of management programs and new therapeutic agents and protocols on
Dovepress

patient perspectives such as quality of life, adherence and satisfaction The manuscript management system is completely online and includes a very quick and fair peer-review system, which is all easy to use. Visit http://www.dovepress.com/testimonials.php to read real quotes from published authors. 